"Technopreneurship (entreprenology) as the Holy Grail of SMEs growth: a historical analysis"

AUTHORS Sivave Mashingaidze

ARTICLE INFO

Sivave Mashingaidze (2016). Technopreneurship (entreprenology) as the Holy Grail of SMEs growth: a historical analysis. Environmental Economics, 7(3), 6774. doi:10.21511/ee.07(3).2016.08

DOI http://dx.doi.org/10.21511/ee.07(3).2016.08

RELEASED ON

Friday, 21 October 2016

JOURNAL

"Environmental Economics"

FOUNDER

LLC "Consulting Publishing Company "Business Perspectives"

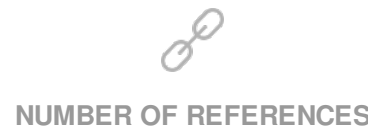

0
NUMBER OF FIGURES

0

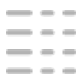

NUMBER OF TABLES

0

C The author(s) 2023. This publication is an open access article. 
Sivave Mashingaidze (South Africa)

\title{
Technopreneurship (entreprenology) as the Holy Grail of SMEs growth: a historical analysis
}

\begin{abstract}
Technopreneurship / entreprenology is a relatively new term and is receiving increasing recognition from the scholars of various streams of business and science and technology disciplines, as well as from the industry players and business men practically. Technopreneurship is, indeed, becoming vital in the current globalization and liberalization economy, as it provides greater opportunities and enables effective optimization of resources to attain high profit margins. This article presents a summary of research on entrepreneurs and discusses the trends in the development of entrepreneurship to present day technopreneurship. It begins by introducing the pioneers of the domain, Cantillon, Say and Schumpeter. The contribution of economists such as Knight, Hayek, Penrose, Kirzner and Casson are mentioned. A second section presents the contributions of the behavioral scientists and the characteristics most commonly ascribed to entrepreneurs. From the 1980s onwards, the field of entrepreneurship detonated and was absorbed into almost every soft science discipline. Two separate trends - one applied, the other theory-based - began to emerge. Thus, the article necessitates that the field is in the process of dividing into two separate entities: entrepreneurship, the applied aspect, and technopreneurship, the theoretical aspect.
\end{abstract}

Keywords: technopreneurship, entreprenology, enterpreneurship, SMEs.

JEL Classification: L26.

\section{Introduction and background}

1.1. Background. The body of entrepreneurship research is eclectic, stratified, and divergent, and it would be an ambitious task to present in this article an all-encompassing robust entrepreneurial historical theory. The multi-faceted and interdisciplinary nature of entrepreneurship sets constraints on such a grandiose and complex task. Generally, entrepreneurship can be described as the bold and imaginative deviation from established business patterns and practice. However, the triumph of entrepreneurship is driven by profound technological change.

Harvard Business School defines entrepreneurship as "the pursuit of opportunity without regards to resources currently controlled". It is not so much a set of skills as a process, a belief, and a commitment. It is a mode of thinking and acting a way of observing the world, of figuring out how to change it hopefully for the better, and, perhaps, most important, of becoming the person who is capable of implementing that change. Skills are important, but skills are commodities (Katz, 2003).

Technopreneurship is basically the merging of two words from two disciplines: technology from the innovation discipline and entrepreneurship from the business discipline. Technology entrepreneurship is, thus, understood in this study as the integration of technological and entrepreneurial realms. More than 1000 publications now appear annually in the field of entrepreneurship, at more than 50 conferences and in 25 specialized journals. This article does not attempt to

(C) Sivave Mashingaidze, 2016

Sivave Mashingaidze, B.Sc., M.Sc., M.Com., Ph.D., Research Fellow Office of Graduate Studies, College of Economic and Management Sciences, University of South Africa, South Africa. cover all the components of the field of entrepreneurship. Its goal is to describe and discuss the core elements of current knowledge on entrepreneurs and to suggest some trends. It presents a summary of a more detailed text on the subject (Bruyat \& Julien, 2001). A number of scholars argue that entrepreneurship is a process that can be applied to the creation of economic or social ends. For example, Drucker (1985) suggested that "the entrepreneur always searches for change, responds to it, and exploits it as an opportunity" (p. 42) regardless of whether that opportunity is commercial or social in nature.

People working in the field of entrepreneurship are convinced that there is a remarkable level of confusion surrounding the definition of the entrepreneur. Researchers tend to perceive and define entrepreneurs using the premises of their own disciplines. Taken from this standpoint, the confusion is perhaps not as great as people would have us believe, because similarities in the perception of the entrepreneur emerge within each discipline. It is often said that confusion reigns in the field of entrepreneurship, because there is no consensus on the definition of the entrepreneur and the boundaries of the paradigm. However, the reverse may also be true entrepreneurship is one of the rare subjects that attracts specialists from such a wide range of disciplines, leading them to discuss and observe what others are doing in related disciplines and question how they are doing it. In fact, the confusion seems greatest if we compare the definitions of the entrepreneur between disciplines (Filion, 1988). For example, the economists have associated entrepreneurs with innovation, whereas the 
behaviorists have concentrated on the creative and intuitive characteristics of entrepreneurs.

1.2. The behaviorist perspective (psychologists, psychoanalysts and sociologists). For the purposes of this article, the term "behaviorists" includes the psychologists, psychoanalysts, sociologists and other specialists of human behavior. One of the first authors from this group to show an interest in entrepreneurs was Weber (2009). He identified the value system as a fundamental element in explaining entrepreneurial behavior. He viewed entrepreneurs as innovators, independent people whose role as business leaders conveyed a source of formal authority. However, the author who really launched the contribution of the behavioral sciences to entrepreneurship was undoubtedly (McClelland, 1987).

McClelland did not define entrepreneurs in the same way as the rest of the literature. His definition was as follows: "An entrepreneur is someone who exercises control over production that is not just for his personal consumption. According to my definition, for example, an executive in a steel-producing unit in the USSR is an entrepreneur." (McClelland, 1971). McClelland's (1971) work concentrated on managers of large organizations. Although he is strongly associated with the field of entrepreneurship, a careful reading of his writings shows that he never made a connection between the need for achievement and the decision to launch, own or even manage a business (Brockhaus, 1982, p. 41). A number of researchers have studied need for achievement, but nobody seems to have obtained conclusive results that associate it with entrepreneurial success (Filion, 1998). After McClelland, the behaviorists dominated the field of entrepreneurship for 20 years, until the early 1980s. Their goal was to define entrepreneurs and their characteristics. The behavioral sciences were expanding rapidly, and there was more consensus than in other disciplines on the most valid and reliable research methodologies. The movement was reflected in research on a number of subjects, including entrepreneurs. Thousands of publications described a whole series of entrepreneurial characteristics. The most common are shown in Figure 1 below.

\begin{tabular}{|l|l|}
\hline 1955 & BBlawatt, \\
\hline $\begin{array}{l}\text { •Meredith, Nelson et al., } 1982 \\
\text { Timmons, }\end{array}$ \\
\hline
\end{tabular}

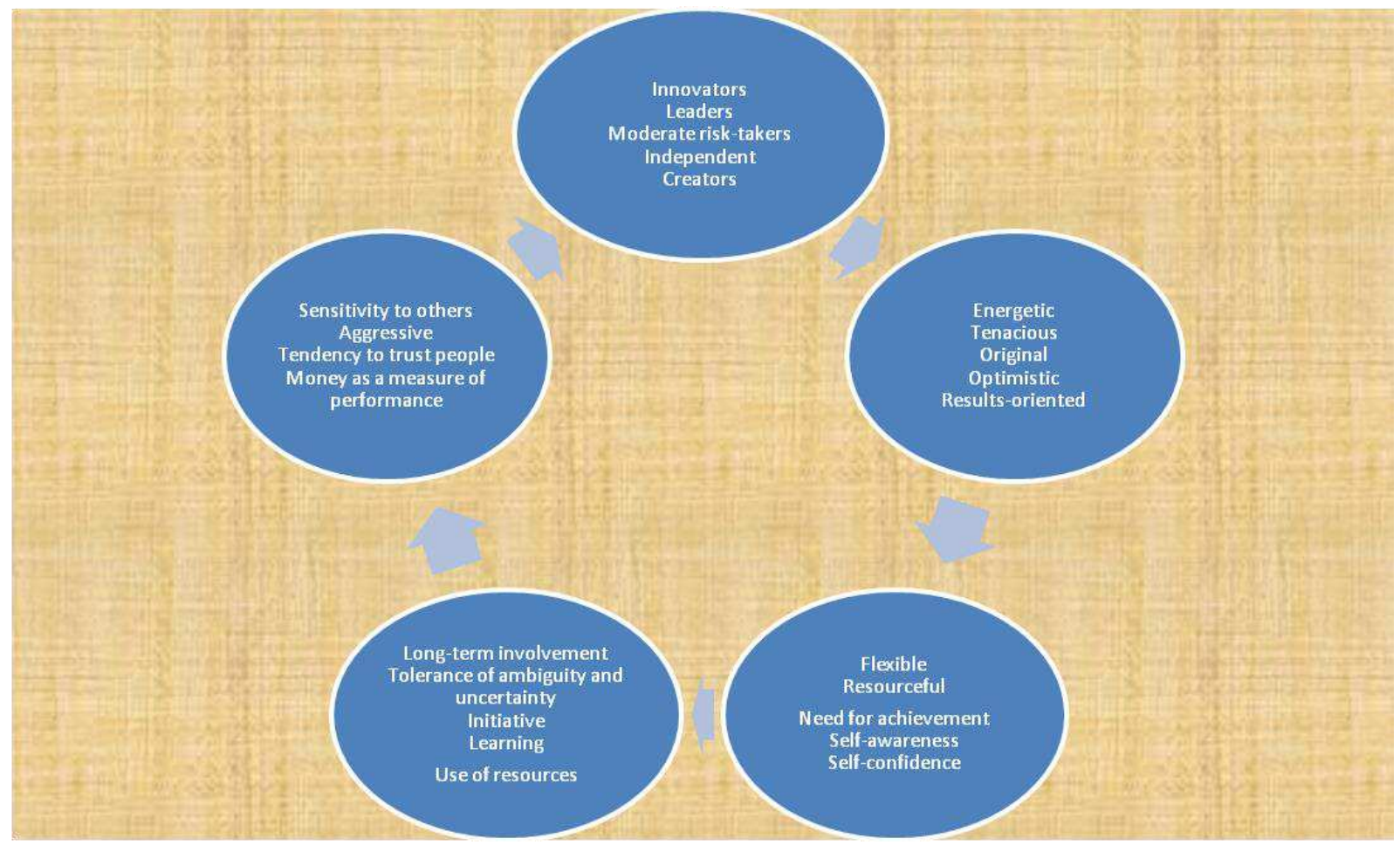

Fig. 1. Behaviorist perspective on entrepreneurial characteristics 
All this research produced highly variable and often contradictory results. So far, it has not been possible to establish an absolute scientific psychological profile of the entrepreneur (Filion, 1991).

\subsection{Environmental determinism of entrepreneurs.}

Human beings are mostly determined by their environments. In reality, one of the conclusions to be drawn with respect to the characteristics of entrepreneurs can be summarized as the social being. So, many researchers have shown that entrepreneurs reflect the characteristics of the period and the place in which they live (Filion, 1998).

The economists have associated entrepreneurs with innovation, the creative and intuitive characteristics of entrepreneurs.

\subsection{Economists' perspective on entrepreneurship} characteristics. First, the article qualifies the popular belief that entrepreneurship originated from the science of economics alone. The first two authors usually identified as the pioneers of the field of entrepreneurship in economics - Cantillon (1755) and Say $(1803,1815,1816,1839)$ - reveal that they were interested not only in the economy, but also in the managerial aspects of enterprises, business development and business management (Cantillon, 1755). Cantillon was basically a banker who, today, would be described as a venture capitalist. His writings reveal a man seeking business opportunities, with a concern for shrewd, economic management and obtaining optimal yields on invested capital.

Origin and development of the term "entrepreneur" by Vérin (1982) revealed that "entrepreneur" acquired its current meaning in the 17th century. Although the term was used before Cantillon, it is clear, as Schumpeter (1954, p. 222) pointed out, that Cantillon was the first to offer a clear conception of the entrepreneurial function as a whole (Frank, 1998). Jean-Baptiste Say was the second author to take an interest in entrepreneurs. He regarded economic development as the result of venture creation, and hoped the English Industrial Revolution would spread to France (Steiner, 2002). Cantillon and Say regarded entrepreneurs as risktakers basically because they invested their own money. In Cantillon's view, entrepreneurs bought a raw material - often a farm product - at a certain price, in order to process it and resell it at an uncertain price. Entrepreneurs were, therefore, people who seized opportunities with a view to making profits, and assumed the inherent risks.

Say drew a distinction between the entrepreneur and the capitalist, and between their profits
(Filion, 1998). In doing so, he associated entrepreneurs with innovation.

$\mathrm{He}$ viewed entrepreneurs as change agents. He himself was an entrepreneur, and became the first to define the boundaries of what an entrepreneur, in the modern sense of the term, actually is. Schumpeter (1954) admitted that a major part of his own contribution was to tell the Anglo-Saxon community about the world of the entrepreneur, as described in the writings of Jean-Baptiste Say. As Say was the first to lay a foundation for the field, we have described him as the father of entrepreneurship (Filion, 1988).

It is perhaps interesting to note that what Say did was basically to draw together two major trends of thought of his time: that of the physiocrats and that of the Industrial Revolution in Great Britain. He was a great admirer of Adam Smith (1776), whose ideas he brought to France, and of the English Industrial Revolution (Say, 1816). In fact, he tried to establish a framework of thought that would enable the Industrial Revolution to move across the Channel to France. He applied the liberal thinking proposed by Quesnay, Mercier de La Rivière, Mirabeau, Condorcet, Turgot and other physiocrats as a means of developing farming, to the entrepreneur (Béraud, \& Steiner, 2008). However, it was Schumpeter who really launched the field of entrepreneurship, by associating it clearly with innovation.

The essence of entrepreneurship lies in the perception and exploitation of new opportunities in the realm of business ... it always has to do with bringing about a different use of national resources in that they are withdrawn from their traditional employ and subjected to new combinations (Schumpeter, 1928). Not only did Schumpeter associate entrepreneurs with innovation, but also his imposing work shows the importance of entrepreneurs in explaining economic development.

In fact, he was not the only one to associate entrepreneurship with innovation. Clark (1899) had done so quite clearly some time before, and Higgins (1959), Baumol (1968), Schloss (1968), Leibenstein (1978) and most of the economists who took an interest in entrepreneurship after him also did the same. The economists were mainly interested in understanding the role played by the entrepreneur as the motor of the economic system (Filion, 1999). From this standpoint, the economists viewed entrepreneurs as "detectors" of business opportunities (Nambisan, S., 2002), creators of enterprises (Ely and Hess, 1893; Oxenfeldt, 1943; Schloss, 1968) and risk-takers (Leibenstein, 1968; Kihlstrom and Laffont, 1979; Buchanan and Di 
Pierro, 1980). Hayek $(1937,1959)$ showed that the role of entrepreneurs was to inform the market of new elements. Knight (1921) showed that entrepreneurs assumed a risk because of the state of uncertainty in which they worked, and that they were rewarded accordingly by the profits they made from the activities they initiated. Hoselitz (1952, 1968) spoke of a higher level of tolerance that enabled entrepreneurs to work in conditions of ambiguity and uncertainty. Casson (1982) made an interesting attempt to develop a theory linking entrepreneurs with economic development. $\mathrm{He}$ emphasized the aspect of resource coordination and decision-making. Leibenstein (1979) had already established a model to measure the level of efficiency and inefficiency in the use of resources by entrepreneurs (Ogunrinola, 1992).

Entrepreneurs are mentioned in economics, but they appear very little - and sometimes not at all - in the classical models of economic development. Where they are present, they are represented by a function. The economists who took an interest in entrepreneurs were usually marginals, as was the case in other disciplines. If we were to summarize the main economic trends of thought on entrepreneurship, we would probably accept the standpoint of Baumol (1993), who proposed two categories of entrepreneurs: the entrepreneurbusiness organizer and the entrepreneur-innovator. The former includes the classical entrepreneur described by Say (1803), Knight (1921) and Kirzner (1983), and the latter the entrepreneur described by Schumpeter (1934).

It is never easy to introduce elements of rationality into the complex behavior of entrepreneurs. One of the criticisms that can be leveled at the economists is that they have not been able to make economic science evolve. They have also been unable to create a science of the economic behavior of entrepreneurs. Casson (1982) went as far as it was possible to go in terms of what is quantifiable and acceptable in economic science. The economists' refusal to accept non-quantifiable models clearly demonstrates the limits of this science in entrepreneurship. In fact, it was one of the elements that led the world of entrepreneurship to turn to the behaviorists for more in-depth knowledge of the entrepreneur's behavior.

1.5. The detonation of the arena of entrepreneurship. In the early $80 \mathrm{~s}$, the field of entrepreneurship exploded and spilled over into almost all the soft sciences and management sciences. The transition was marked by two events: the publication of the first-ever encyclopedia containing the state of the art in the field (Kent,
Sexton \& Vesper, 1982), and the first major annual conference dedicated to research in the new field. It is interesting to note that the development of entrepreneurship as a discipline did not follow the same pattern as other disciplines. In fact, large numbers of researchers, each using a culture, logic and methodology established to varying degrees in their own fields, began to take an interest and work in the field of entrepreneurship. The first doctoral graduates in entrepreneurship and small business appeared in the 1980s (Kent, Sexton \& Vesper, 1982). Nevertheless, the vast majority of those interested in the field were from disciplines other than entrepreneurship, and the study of entrepreneurship was not their main field of activity. Now, however, more people are devoting time and effort exclusively to entrepreneurship. The number of venture creations is growing, and the share of GNP attributable to small business in all countries is increasing every year. To follow the evolution and needs of their students and clients, many professors have to learn more about entrepreneurship and small business. Thus, the assimilation and integration of entrepreneurship into the other disciplines, especially the soft sciences and management sciences, is unique as a phenomenon, and has never before occurred to such an extent in the paradigmatic construction of a soft science discipline (Filion, 1999).

1.6. Definition consensus of entrepreneurship and the boundaries of the paradigm. It is often said that confusion reigns in the field of entrepreneurship, because there is no consensus on the definition of the entrepreneur and the boundaries of the paradigm. However, the reverse may also be true - entrepreneurship is one of the rare subjects that attracts specialists from such a wide range of disciplines, leading them to discuss and observe what others are doing in related disciplines and question how they are doing it. In fact, the confusion seems greatest if we compare the definitions of the entrepreneur between disciplines (Filion, 1988). On the other hand, if we compare the definitions produced by specialists within the same field, we find a quite astonishing consensus. The economists tend to agree that entrepreneurs are associated with innovation, and are seen as the driving forces of development. The behaviorists ascribe the characteristics of creativity, persistence, locus of control and leadership to entrepreneurs. Engineers and operations management specialists see entrepreneurs as good distributors and coordinators of resources.

Finance specialists define entrepreneurs as people able to measure risk. For management specialists, 
entrepreneurs are resourceful and good organizers, develop guidelines or visions around which they organize their activities, and excel at organizing and using resources. Marketing specialists define entrepreneurs as people who identify opportunities, differentiate themselves and adopt customeroriented thinking. For students of venture creation, the best elements for predicting the future success of an entrepreneur are the value, diversity and depth of experience and the skills acquired by the would-be entrepreneur in the sector in which he or she intends to operate (Filion, 1988).

The field of entrepreneurship has attracted the interest of specialists from almost all the soft science disciplines in the last decade. The apparent confusion basically reflects the differing logic and cultures of these disciplines. It seems likely that, in the coming decade, entrepreneurship will become one of the main gathering points of the soft sciences, because it is one of the rare subjects that has attracted such a large number of specialists from such a wide range of disciplines.

1.7. Progression for theory building. In every discipline, there is a desire to understand trends and formulate universal laws around which knowledge can be structured. The fields of entrepreneurship and small business are no exception to this. We have reached a point where many people are calling for a robust theory based on universal axioms, such as that which exists in physics, for example. The theory would be based on rigorous quantitative models and would be obtained by means of wideranging quantitative research that would incontestably prove the nature of the entrepreneur, entrepreneurial activity and its effects on economic development (Filion, 1988). At the same time, thousands of teachers are faced every day with the need to produce material to train entrepreneurs for entrepreneurial practice. To do this, they use qualitative methods to develop models and tools that will help actual and potential entrepreneurs to practice their profession competently. This tension between academics who write for other academics, on the one hand, and academics who write for practitioners, on the other hand, is strong enough in the field to deserve attention here. This may be the starting point of two complementary disciplines: entrepreneurship, i.e., research where the client is a practitioner, and entreprenology, i.e., research where the client is another researcher (Filion, 1988).

Filion (2003) posited that many attempts at theorizing have been made. The most frequently quoted include: Amit, Glosten et al. (1993), Baumol (1993), Bull and Willard (1993), Bull, Thomas et al. (1995), Bygrave (1989a, 1989b), Casson (1982),
Collins and Moore (1970), Covin and Slevin (1991), Gartner (1985, 1990), Gartner, Carland et al. (1988), Hébert and Link (1982), Hofer and Bygrave (1992), Leibenstein (1968), Low and MacMillan (1988), Peterson and Ainslie (1988), Reynold (1991), Sombart (1928), and Stevenson and Jarillo (1990). Viewed from another agle at all these theorybuilding efforts in the field of entrepreneurship, it becomes clear, as Mulholland (1994) pointed out, that the link established by Schumpeter (1928, 1934) between the entrepreneur and innovation has remained a dominant feature of the discipline, especially among the economists. For the economists, the innovation-based definition and approach developed by Schumpeter to explain the entrepreneur are sufficient to develop a theory of entrepreneurship (Kirchhoff, 1992, 1994). Julien (1989) has already pointed out the difficulty of aligning economics with the other soft sciences. In fact, when we compare the standpoints of Baumol (1990, 1993) and Casson (1982), the fundamental differences existing even between the economists themselves become obvious (Shane \& Venkataraman, 2000).

\section{Structure and theory in the field of entrepreneurship}

Cunningham and Lischeron (1991) suggested that the field of entrepreneurship is being structured around six points:

- the "great man" school, the psychological characteristics school;

- the classical (innovation) school;

- the management school;

- the leadership school and the intrapreneurship school.

Blawatt (1995), cited by Robichaud, McGraw \& Alain (2001) using these and other characteristics, proposed that a conceptual model of entrepreneurship should include the performance criterion. He observed that most of the models proposed by the school of personality and others are generally static. He aligned himself with authors who have studied entrepreneurs in the field, and observed that entrepreneurs work in an evolving context where activities and roles change gradually. Entrepreneurs learn from what they do (Collins and Moore, 1970; Filion, 1996), and because the nature of what they do changes, they must change as well. They, therefore, have to learn to play different roles as their business evolves (Robichaud, McGraw \& Alain, 2001). Bygrave (1989) suggested that what we need most is qualitative field research to understand what entrepreneurs do (1989a). He, then (1989b), proposed the chaos theory in physics as an 
interesting basis for a theory of entrepreneurship, but, nevertheless, warned that chaos is "no more than a mathematical metaphor, because the accuracy of measurements necessary ... are unattainable in process" (1993).

Déry and Toulouse (1996) analyzed the themes addressed and the references used in one of the most frequently-quoted journals in the field of entrepreneurship, the Journal of Business Venturing (Cooper, Gimeno-Gascon \& Woo, 1994). They observed that more than half the references referred to books and similar research in the field of strategy, based on an analysis of quotations in the Strategic Management Journal showed that more than half the references were academic articles. This seems to suggest that the field of strategy is now mature enough for researchers to have reached a certain consensus.

In entrepreneurship, according to Déry and Toulouse (1996), still a paradigm is being developed where no consensus has yet been reached as regards the theoretical construction of the discipline. It may also be that the field of entrepreneurship is being structured in a different way from the other soft sciences, including strategy. While psychology emerged from philosophy (Miller, 1962), and psychoanalysis from medicine and psychology, the field of entrepreneurship is rooted in practically all the soft sciences and management sciences. Entrepreneurship research addresses both theoretical and practical elements. It would, therefore, not be surprising if theories were to emerge from sets of applied research. The soft sciences are composed mainly of flexible interpretative models. Any theory of entrepreneurship must be flexible and multidimensional to reflect its multidisciplinary roots. Before any theory is found, another, very important emerged called "Technopreneurship" which is founded by merging two words "Technology and Entrepreneurship". It is a "technology innovator and business man rolled into one"; or better still "an entrepreneur whose business involves technology related activities". They are naturally gifted, smart, creative, but not necessarily formally educated; aggressive young men \& women passionate for success; mostly assemblers and, at times, innovators. The number of entrepreneurs globally is now about 400 million, the Global Entrepreneurship Monitor (GEM) 2011 Global Report revealed (Kelley, Singer \& Herrington, 2012).

2.1. $21^{\text {st }}$ century human capital development for technopreneurship. Technopreneurship - merging technology process and entrepreneurial skills is the real source of power in today's knowledge-based economy. A technopreneur distinguishes logic from tradition, tradition from prejudice, prejudice from common sense and common sense from nonsense while integrating a variety of ideas from diverse groups and disciplines. Peter Drucker defines innovation as the systematic act of turning "something" (product, idea, information, technology, etc.) into a resource that is of high value to its target market. And this skill an enterpreneus needs education to have it. He cites the example of transforming bauxite-formerly considered a nuisance, because it did nothing, but make land infertile-to aluminum which is now considered important to the world economy because of its many applications. According to Drucker, technology is not necessarily "hi-tech", indeed, does not always have to be technical. Technology is simply defined as applications of knowledge to human work. Thus accounting, Economic Order Quantity, word-ofmouth marketing, and well-defined mentoring programs are all technologies.

Entrepreneurial skills will drive economy back to prosperity. Technopreneurship is not a product, but a process of synthesis in engineering the future of a person, an organization, a nation and the world. Strategic directions or decision-making processes are becoming more demanding and complex. This requires universities, and in site professional development programs and training to produce strategic thinkers who will have skills to succeed in a rapidly changing global environment.

\subsection{Involvement of education systems in technopreneurship. Traditional university} programs, however, lack the teaching methods to turn today's students into creative, innovative, visionary global leaders who understand the importance of technopreneurship. Recent technological advances and global competitiveness have changed and broadened the nature of liberal arts to embrace humans and machines. The answer is not creating new liberal arts or soft-skills courses, but integrating them into the general technical curriculum. These changes take time. Also, what about present and past universities' graduates? The solution is to increase in site training and development at all levels of a corporation. Creativity is breaking the conventional mental blocks and playing with imagination and possibilities, leading to new and meaningful connections and outcomes while interacting with ideas, people and the environment. Technopreneurship is the only source of long-run sustainable competitive advantage. In an era of manmade brainpower industries, individual, corporate, and national economic success will all require both 
new and more extensive skills sets than have been required in the past. By themselves, skills don't guarantee success. They have to be put together in successful organizations. But without skills and technopreurship there are no successful organizations (Abeyrathne et al., 2015).

But these programs should focus on what workers and professionals should be able to do. These include functioning on multidisciplinary teams, communicating effectively, acquiring updated knowledge of technological developments, and understanding the basic technical concepts and there new applications and improvements.

Education at all levels - schools, technical institutes, universities and companies - needs meaningfully to enable ongoing achievement of excellence, and to encourage curiosity, flexibility and creativity. Together with investment in technological change, continuous development of company personnel will drive growth, productivity, wealth creation and social stability at both the national and international levels.

\section{Conclusion}

The research has seen that entrepreneurship was first identified by the economists as a useful element for understanding development. Subsequently, the behaviorists tried to understand the entrepreneur as a person. However, the field is currently in the midst of an explosion, in that it is spreading into almost every other soft science discipline. The research agreed with Mulholland (1994) and Rosa and
Bowes (1990) that the field is still dominated by the positivist-functionalists, and that there is an urgent need to open up new perspectives in order to understand what entrepreneurs are and what they do. In light of the above, the field of entrepreneurship can be defined as the field that studies entrepreneurs. It examines their activities, characteristics, economic and social effects and the support methods used to facilitate the expression of entrepreneurial activity. No academic field can allow itself to neglect theory. However, to create a theory of the entrepreneur, it will probably be necessary to separate applied research from theoretical research by establishing a new science, technopreneurship / entreprenology. This new science could create a theoretical corpus composed of the convergent elements of theoretical studies of entrepreneurs by entreprenologists in the various disciplines. Technopreneurship itself would continue as an applied research field, producing results of interest to practicing and potential entrepreneurs. Global Entrepreneurship Monitor researches offer several guidelines for policymakers, entrepreneurs, and academic to help them to build entrepreneurial eco-systems that enable entrepreneurship thrive in every world economy. "Policy recommendations that improve the flexibility of labor, communications and market openness, while eliminating bureaucracy and redtape will contribute to a more entrepreneuriallyfocused business environment". But education is the pillar and life of technopreneurship and should be adopted in policy reforms in governments and all policy-makers.

\section{References}

1. Abeyrathne, G.D., Habaragamuwa, I.D., Holipitiya, G.P., Indrachapa, R.G.P., Jayawardana, L.J., Nandasiri, D.L. \& Javid, H.J.M. (2015). Technology Adaptation of Apparel Industry in Sri Lanka: An Observational Survey.

2. Béraud, A. \& Steiner, P. (2008). France, Economics in, before 1870, The New Palgrave Dictionary of Economics, pp. 3-475.

3. Blawatt, K.R. (1995). Entrepreneurship in Estonia: Profiles of entrepreneurs, Journal of Small Business Management, 33(2), p. 74.

4. Bruyat, C. \& Julien, P.A. (2001). Defining the field of research in entrepreneurship, Journal of business venturing, 16(2), pp. 165-180.

5. Bygrave, W.D. (1989). The entrepreneurship paradigm (I): a philosophical look at its research methodologies, Entrepreneurship Theory and practice, 14(1), pp. 7-26.

6. Cantillon, R. (1755), Essay on the nature of general commerce. Henry Higgs, trans. London: Macmllan.

7. Cooper, A.C., Gimeno-Gascon, F.J. \& Woo, C.Y. (1994). Initial human and financial capital as predictors of new venture performance, Journal of business venturing, 9(5), pp. 371-395.

8. Cunningham, J.B. \& Lischeron, J. (1991). Defining entrepreneurship, Journal of small business management, 29(1), pp. 45-61.

9. Déry, R. \& Toulouse, J.M. (1996). Social structuration of the field of entrepreneurship: a case study, Canadian Journal of Administrative Sciences/Revue Canadienne des Sciences de l'Administration, 13(4), pp. 285-305.

10. Filion, L.J. (1991). Vision and relations: elements for an entrepreneurial metamodel, International Small Business Journal, 9(2), pp. 26-40.

11. Filion, L.J. (1998). Do empreendedorismo à empreendedologia. Traduzido e adaptado por Jovino Moreira da Silva. Disponível em: http://www. uesb. br/sheng/4. pdf.

12. Filion, L.J. (1999). Empreendedorismo: empreendedores e proprietários-gerentes de pequenos negócios, Revista de Administração, 34(2), pp. 5-28. 
13. Filion, L.J. (2003). Emprendedores y propietarios-dirigentes de pequeña y mediana empresa (PME), Revista de Administración de Empresas, 34(2), pp. 5-28.

14. Frank, M.W. (1998). Schumpeter on entrepreneurs and innovation: a reappraisal, Journal of the History of Economic Thought, 20(04), pp. 505-516.

15. Kelley, D.J., Singer, S. \& Herrington, M. (2012). The global entrepreneurship monitor. 2011 Global Report, GEM 2011,7 .

16. Kent, C.A., Sexton, D.L. \& Vesper, K.H. (1982). Encyclopedia of entrepreneurship. University of Illinois at Urbana-Champaign's Academy for Entrepreneurial Leadership Historical Research Reference in Entrepreneurship.

17. McClelland, D.C. (1987). Human motivation. CUP Archive.

18. Nambisan, S. (2002). Software firm evolution and innovation-orientation, Journal of Engineering and Technology Management, 19(2), pp. 141-165.

19. Ogunrinola, I.O. (1992). Determinants of Entrepreneurship Development in the Urban Informal Sector of Lagos, Africa Development/Afrique et Développement, pp. 81-97.

20. Robichaud, Y., McGraw, E. \& Alain, R. (2001). Toward the development of a measuring instrument for entrepreneurial motivation, Journal of developmental entrepreneurship, 6(2), p. 189.

21. Say, J.B. (1816). Catechism of Political Economy: Or, Familiar Conversations on the Manner in which Wealth is Produced, Distributed, and Consumed in Society. Sherwood, Neely, and Jones.

22. Schumpeter, J. (1928). The instability of capitalism, The economic journal, 38(151), pp. 361-386.

23. Shane, S. \& Venkataraman, S. (2000). The promise of entrepreneurship as a field of research, Academy of management review, 25(1), pp. 217-226.

24. Steiner, P. (2002). JEAN-BAPTISTE SAY: THE ENTREPRENEUR, THE FREE. Studies in the History of French Political Economy: From Bodin to Walras, 196.

25. Vérin, H. (1982). Entrepreneurs, entreprise: histoire d'une idée (Vol. 2). Presses universitaires de France.

26. Weber, M. (2009). From Max Weber: essays in sociology. Routledge. 